\title{
OTONOMI PENDIDIKAN DAN EKSISTENSI MADRASAH
}

\author{
$\mathscr{H}$ kmal $\mathcal{O H a n i}$ \\ Program Pascasarjana \\ Universitas Islam Negeri Raden Fatah Palembang \\ E-mail:akmalhawi_uin@radenfatah.ac.id
}

\begin{abstract}
The policy of regional autonomy has also implicated the education sector with the concept of decentralization of education, which aims to provide widespread authority to regulate and manage madrasah (local authorities) in the framework of improving the quality of education for all levels of society. Madrasah as one of the educational institutions that take shelter in the Department of Religion inevitably come into contact with the issue of educational autonomy. But the problem is whether the Department of Religion remains in the position of the autonomous rights holder for the entire education system in the madrasah or only limited to religious subjects only. A consistent, cautious but definite and nondisadvantageous attitude to the Department of Religion needs to be addressed in a special discussion.
\end{abstract}

Keywords: Regional Autonomy, Decentralization of Educationm, the Existence of Madrasahs.

\begin{abstract}
Abstrak
Kebijakan otonomi daerah telah berimplikasi pula pada bidang pendidikan dengan konsep desentralisasi pendidikan, yang bertujuan memberikan kewenangan secara luas untuk mengatur dan mengelola madrasah (pihak daerah) dalam kerangka meningkatkan mutu pendidikan bagi seluruh lapisan masyarakat. Madrasah sebagai salah satu lembaga pendidikan yang bernaung di Departemen Agama mau tidak mau bersentuhan juga dengan isu otonomi pendidikan tersebut. Tetapi yang menjadi masalah adalah apakah Departemen Agama tetap dalam posisi pemegang hak otonom bagi keseluruhan sistem pendidikan di madrasah ataukah hanya dibatasi pada mata pelajaran agama saja. Sikap yang konsisten, hatihati tetapi pasti dan tidak merugikan pihak Departemen Agama perlu dikancah dalam diskusi khusus.
\end{abstract}

Kata kunci: Otonomi daerah, Desentralisasi pendidikan dan Eksistensi Madrasah. $\begin{array}{crr}\text { Undang-udang } & \text { Otonomi } & \text { Daerah } \\ \text { meletakkan kewenangan } & \text { sebagian } & \text { besar }\end{array}$ pemerintahan bidang pendidikan dan kebudayaan yang selama ini berada pada pemerintah pusat kepada pemerintah daerah (Kabupaten/Kota). Kewenangan yang tersisa pada pemerintah pusat dan provinsi hanya sebatas besarannya saja (Lihat Peraturan Pemerintah No.25 Tahun 2000).

Otonomi daerah dilakukan untuk meningkatkan kesejahtraan rakyat, pemerataan keadilan, demokratisasi dan penghormatan terhadap nilai-nilai budaya lokal serta menggali potensi dan keanekaragaman daerah. Bukan untuk memindahkan masalah dari pusat ke kabupaten/kota. Demikian juga otonomi pendidikan, bertujuan untuk meningkatkan mutu pendidikan bagi seluruh lapisan masyarakat, bukan memindahkan atau mengembangbiakkan masalah pendidikan yang menjadi beban pemerintah pusat ke kabupaten dan kota.

Dengan demikian, kabupaten dan kota perlu memilah dan memilih secara hati-hati berbagai strategi pembangunan pendidikan yang selama ini telah dilakukan agar kekeliruan kolektif pada masa lalu tidak diulangi oleh kabupaten dan kota pada masa yang akan datang. Oleh karena itu, hanya strategi pembangunan pendidikan yang menunjukkan pengaruh positif yang perlu dilanjutkan, sedangkan yang tidak banyak memberi manfaat bagi siswa, sekolah (madrasah) serta yang akan melahirkan masalah baru harus segera ditinggalkan.

Otonomi pendidikan di atas, langsung atau tidak langsung telah mengangkat satu isu penting yang berkenaan dengan kedudukan madrasah baik dalam hal sistem maupun pengelolaannya (manajemen). Dalam hal ini, madrasah sebagai satu lembaga pendidikan (Islam) dipahami sebagai akar dualisme pendidikan di Indonesia. Konsekuensi 


\section{Haril Penelitian}

logisnya adalah muncul kembali obsesi untuk menyatu-atap-kannya.

\section{Posisi Madrasah di Era Otonomi Daerah}

Sebelum membicarakan posisi madrasah di era otonomi daerah, perlu terlebih dahulu membaca ulang jati diri madrasah itu sendiri. Dengan demikian diharapkan, siapapun, tidak tergesa-gesa mengambil keputusan atau merumuskan kebijakan yang berkenaan dengan keberadaan mayoritas umat Islam dan sejarah bangsa serta perkembangan Islam itu sendiri.

\section{Sejarah Madrasah}

Madrasah sebagai lembaga pendidikan Islam di Indonesia telah muncul dan berkembang seiring dengan masuk dan berkembangnya Islam di Indonesia. Madrasah tersebut telah mengalami perkembangan jenjang dan jenisnya seirama dengan perkembangan bangsa Indonesia sejak masa kesultanan, masa penjajahan dan masa kemerdekaan. Perkembangan tersebut telah mengubah pendidikan dari bentuk awal seperti pengajian di rumah-rumah, mushallah dan masjid mejadi lembaga formal sekolah seperti bentuk madrasah yang dikenal sekarang ini.

Menelusuri sejarah pertumbuhan dan perkembangannya, Madrasah, ternyata tidak dapat dipisahkan dari perkembangan masyarakat, atau tegasnya semua aspek kehidupan masyarakatnya. Diantara aspek yang dapat dikatakan menonjol dalam mempengaruhi perkembangan Madrasah itu sejak masa klasik ialah aspek politik dan pemikiran keagamaan. Karena itu, melihat sejarah Madrasah bukan semata-mata sejarah kelembagaan pendidikan Islam, tetapi juga sejarah politik dan pemikiran keagamaan.

Pera penulis sejarah pendidikan Islam di Indonesia, agaknya sepakat dalam menyebut beberapa Madrasah pada periode pertumbuhan khususnya di wilayah-wilayah Sumatera dan Jawa. Mahmud Yunus memasukkan ke dalam Madrasah kurun pertumbuhan ini antara lain Adabiah School (1909) dan Diniah School Labai al-Yunusy (1915) di Sumatera Barat. Madrasah Nahdatul Ulama di Jawa Timur, Madrasah Muhammadiyah di Yogyakarta, Madrasah Taswiq Thullab di Jawa Tengah, Madrasah Persatuan Umat Islam di Jawa Barat, Madrasah Jum'iyat Kheir di Jakarta,
Madrasah Amiriah Islamiah di Sulawesi, dan Madrasah Assulthaniyyah di Kalimantan.

Salah satu ciri penting dari madrasahmadrasah periode pertumbuhan adalah bahwa eksistensinya antara satu sama lain masih terpisahpisah. Usaha mendirikan Madrasah masih bersifat pribadi atau organisasi dalam pengertian sempit. Madrasah-madrasah di Padang tidak memiliki hubungan langsung maupun tidak langsung dengan Madrasah-madrasah di Jawa. Tidak ada pengaturan yang bersifat umum dan mengikat mengenai bentuk kelembagaan, struktur manajemen dan kurikulumnya. Seperti diisyaratkan oleh Steenbrink dalam Maksum (1999:98), bahwa "usaha pendirian Madrasah itu bertolak dari motif masing-masing, namun semuanya mengarah pada peningkatan peran umat Islam”. Dengan demikian, uniformitas pada Madrasah-madrasah itu hanya dapat dilihat dalam hal sistem pendidikannya yang berkelas dan isi pendidikannya yang memberi perhatian pada ilmu-ilmu agama.

Berdasarkan uraian di atas dapat dikemukakan bahwa Madrasah pada permulaan perkembangannya merupakan lembaga pendidikan yang mandiri (swadana dan swakelola), tanpa bimbingan dan bantuan materil dari pemerintah (Kolonial Belanda). Setelah Indonesia merdeka, pemerintah (NKRI) memberikan perhatian kepada Madrasah dan ditetapkan sebagai model dan sumber pendidikan nasional yang berdasarkan UUD 1945 (Asrohah, 1999:194). Untuk itu, BPKNIP (Badan Pekerja Komite Nasional Indonesia Pusat) sebagai Badan Pekerja Majelis Permusyawaratan Rakyat pada masa itu merumuskan pokok-pokok usaha pendidikan, yang menetapkan bahwa: "Madrasah dan Pesantren yang pada hakikatnya adalah satu alat dan sumber pendidikan dan pencerdasan rakyat jelata yang sudah berurat berakar dalam masyarakat Indonesia umumnya, hendaklah pula mendapat perhatian dan bantuan yang nyata berupa tuntunan dan bantuan materil dari pemerintah" (Asrohah, 1999:194). Dalam rangka memperkukuh eksistensi Madrasah sebagai komponen pendidikan nasional, artinya diakui sebagai penyelenggara kewajiban belajar, sebagaimana tercantum dalam Undang-Undang Pokok Pendidikan dan Pengajaran Nomor 4 Tahun 1950, pada Pasal 10 ayat 2 dinyatakan bahwa belajar di sekolah-sekolah agama yang telah 


\section{Hagil Penelition}

mendapat pengakuan dari Menteri Agama dianggap telah memenuhi kewajiban belajar.

Selanjutnya, seiring dengan perkembangan zaman dan peta politik bangsa, Madrasah dengan berbagai kebijakan pemerintah semakin mendapat pengakuan dan menempati posisi yang strategis karena peranannya dalam mencerdaskan kehidupan bangsa (cerdas intelektual, cerdas emosional dan cerdas spritual) terasa semakin dibutuhkan.

\section{Otonomi Madrasah dan Eksistensi Departemen Agama}

Sejarah panjang lembaga pendidikan Islam (Madrasah) yang keberadaannya (dibangun dan dikembangkan) secara swadana dan swakelola sebagaimana telah dikemukakan di atas membuktikan betapa umat Islam (sebagai penduduk mayoritas di NKRI) menaruh kepedulian yang besar terhadap nasib anak bangsa. Kepedulian yang besar ini telah disikapi dengan bijak oleh pemerintah dengan menyerahkan pengelolaan lembaga pendidikan Islam (Madrasah) sepenuhnya di bawah Departemen Agama. Kebijakan ini bukan saja merupakan kebijakan pendidikan tetapi juga merupakan kebijakan politis yang memang demikianlah seharusnya.

Bukankah diakuinya lembaga pendidikan agama dengan berbagai kebijakan pemerintah seperti telah dikemukakan di atas bukan sekedar ungkapan rasa terima kasih negara atas perjuangan umat Islam melawan penjajah, lebih dari itu, karena lembaga pendidikan Islam (Madrasah) adalah suatu kebutuhan. Mengalihkan pengelolaan Madrasah ke Instansi lain sama saja artinya menghapuskan sejarah dan peran umat Islam, dan akan dianggap oleh umat Islam sebagai upaya pelan-pelan menyingkirkan Madrasah. Jika Madrasah dipindahtangankan dari Departemen Agama ke Departemen lain (Pemkot/Pemda) maka Departemen Agama akan kehilangan sekian persen fungsinya. Dengan begitu, bukan tidak mungkin kemudian orang akan mempertanyakan fungsi penerangan agama dan peradilan agama. Apakah tidak lebih baik juga dipindahkan ke Departemen Penerangan dan Kehakiman. Demikian pula bidang-bidang lainnya. Jika sudah demikian, semakin tidak jelas eksistensi Departemen Agama. Selanjutnya bukan tidak mungkin akhirnya hilang (dihilangkan).
Jika dengan otonomi daerah kita berhasrat untuk membangun usaha debirokratisasi, desentralisasi, dan deregulasi. Mengapa dalam bidang pendidikan mempertahankan sentralisasi. Jika yang dimaksudkan adalah dalam rangka nation building, itu sah-sah saja. Tetapi bukan demikian caranya. Yang penting bukan pemindahtanganan atau penyatu-atap-an, tetapi satu sistem pendidikan nasional. Dan ini sudah dirumuskan dalam GBHN. Oleh karena itu, pemindahtanganan pengelolaan Madrasah dari Departemen Agama ke Departemen lain (Pemkot/Pemda) diperlukan pemikiran yang mendalam dan hati-hati dengan tetapi memberikan penghargaan terhadap gagasan awal dari otonomi daerah itu sendiri.

Sistem Pendidikan Nasional itu maksudnya adalah bahwa dalam negara ini hendaknya ada fungsionalisasi. Penanggung jawab pendidikan adalah Depdiknas. Penanggung jawab keagamaan adalah Departemen Agama. Penanggung jawab pertahanan dan keamanan adalah Departemen Hankam, dan seterusnya. Ini yag fundamental. Pelaksananya bisa dibeberapa atap. Yang mengatur kualitas pendidikan tetap Depdiknas. Depdiknas lah yang menetapkan pengetahuan minimal apa yang harus dimiliki anakanak Indonesia.

Beranjak dari pemahaman ini maka dimungkinkan adanya pendidikan kepegawaian dan administrasi oleh Depnaker. AKABRI oleh Hankam dan lain-lain. Penanggung jawab utama ada di Depdiknas, tetapi lembaga dan departemen lain bukan tidak boleh menyelenggarakan pendidikan.

Jika ada kebijakan umum yang ditangani oleh Depdiknas, tentu saja lembaga atau departemen lain diperkenankan mengeluarkan kebijakan khusus, karena kekhasan lembaga pendidikan itu. AKABRI misalnya memiliki kekhasan tertentu, demikian juga yang lainnya. Tetapi dalam hal tertentu, misalnya memberikan gelar kelulusan AKABRI atau yang lainnya tidak diperkenankan untuk mengeluarkan ketentuan tersendiri. Dengan adanya kebijakan itu, masalah satu atap menjadi tidak realistis. Soalnya, ada keahlian-keahlian dan kebutuhan-kebutuhan tertentu yang menjadi kewenangan dan keahlian suatu departemen. 


\section{Hasil Penelitian}

\section{Kesimpulan}

Demikian pokok-pokok pemikiran (wacana) mengenai Madrasah dan Departemen Agama dalam kaitannya dengan otonomi daerah/otonomi pendidikan. Sebagai suatu bahan diskusi sudah tentu tulisan ini belum lengkap dan untuk itu diharapkan masukan-masukan yang konstruktif dari berbagai pihak sehingga melalui media ini kita dapat memperoleh dan merumuskan secara tegas kebijakan otonomi pendidikan yang berkenaan dengan eksistensi Madrasah.

\section{Daftar Pustaka}

Abuddin Nata. Paradigma Pendidikan Islam. Jakarta: PT. Gramedia Widiararana Indonesia. 2001
Abd. Rahman Shaleh. Penyelenggaraan Madrasah; Peraturan Perundangan. Jakarta: Dharma Bakti. 1984.

Harun Asrohah. Sejarah Pendidikan Islam. Jakarta: PT. Logos Wacana Ilmu. 1999.

Husni Rahim. Arah Baru Pendidikan Islam di Indonesia. Jakarta: PT. Logos Wacana Ilmu. 2001.

Indra Djati Sidi. Menuju Masyarakat Belajar; Menggagas Paradigma Baru Pendidikan. Jakarta: Paramadina. 2001.

Mahmud Yunus. Sejarah Pendidikan Islam. Jakarta: Hidakarya Agung. 1989.

Maksum. Madrasah; Sejarah dan Perkembangannya. Jakarta: PT. Logos Wacana Ilmu. 1999. 